\title{
GEO-EYE
}

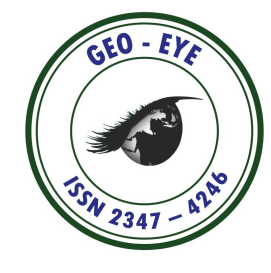

RESEARCH ARTICLE

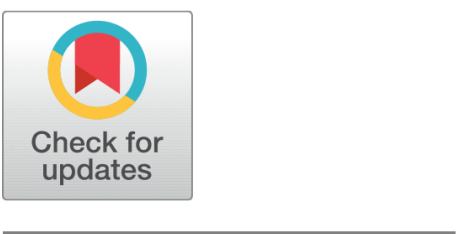

G OPEN ACCESS

Received: 17.02.2020

Accepted: 21.05 .2020

Published: 02.06.2020

Citation: Irfan S, Hanjagi AD. (2020). EVALUATION OF CARTO SAT DEM-DERIVED MORPHOMETRIC PARAMETERS - A CASE STUDY ON ARKAVATHI WATERSHED OF KARNATAKA, INDIA. Geo-Eye. 9(1): 49-56. https://doi.org/ 10.53989/bu.ge.v9i1.10

Corresponding author.

shahninirfan27@gmail.com

Funding: None

Competing Interests: None

Copyright: (c) 2020 Irfan \& Hanjagi. This is an open access article distributed under the terms of the Creative Commons Attribution License, which permits unrestricted use, distribution, and reproduction in any medium, provided the original author and source are credited.

Published By Bangalore University, Bengaluru, Karnataka

ISSN

Print: 2347-4246

Electronic: XXXX-XXXX

\section{EVALUATION OF CARTO SAT DEM-DERIVED MORPHOMETRIC PARAMETERS - A CASE STUDY ON ARKAVATHI WATERSHED OF KARNATAKA, INDIA}

\author{
Shahnin Irfan ${ }^{1 *}$, Ashok D Hanjagi ${ }^{2}$ \\ 1 Research Scholar, Department of Geography, Bangalore University, Bangalore 56 \\ 2 Professor, Department of Geography, Bangalore University, Bangalore-56
}

\begin{abstract}
In the present study morphometric analysis of Arkavathi watershed is based on remote sensing and geographic information systems. The morphometric parameters are calculated with Carto sat DEM using Arc GIS 10.3 extension and Arc Hydrology tool in order to characterize it quantitatively. The current study involved determining the linear, aerial, and relief dimensions of the eight sub-watersheds for soil and water planning and management of the watershed. The watershed characterizes to have a dendritic pattern of drainage which has a medium stream frequency and moderate drainage density. Circularity ratio and form factor values indicate that sub watersheds are more or less elongated. The Length of the overland flow has a high value with gentle slopes and long flow paths. Understanding the procedures and methods of various morphometric factors can thus be used to prioritize watersheds for management, rainwater collection, and conservation planning.
\end{abstract}

Keywords: Morphometric Analysis; Carto SATDEM; Remote Sensing; GIS

\section{Introduction}

The entire area that provides runoff to and retains part or all of the stream flow of the main stream and its tributaries is referred to as a watershed(Prabhakaran \& Jawahar Raj, 2018). The climate, geology, geomorphology, and relief elements of a basin are often highlighted during drainage network delineation and parameter analysis (Sharma et al., 2016). Understanding the impact of drainage morphometry on landscapes and their char- acteristics requires a detailed morphometric analysis of a watershed (Chandrashekar et al., 2015). The morphometric analysis of a river basin thus provides the first hand information to understand the geomorphology and watershed characteristics. The channel network uses morphometric analysis to understand the drainage basin's geo-hydrological behavior and expresses the catchment's current climate, geology, geomorphology, structural, and other factors. 'Many workers are aware of the relationship between 
various drainage parameters and the aforesaid factors' (Chorley, 1995; Obi Reddy et al., 2004; Paulinus et al., 2016). Because all hydrological and geomorphic processes occur within the watershed, using it as a basin unit in morphometric analysis is the most logical choice (Dikpal et al., 2017). When doing morphometric analysis of a watershed, there are three main considerations, which are linear, Areal and Relief aspects. Linear aspects are used to define onedimensional parameters like Stream Order, Stream Number, and Bifurcation Ratio. Two-dimensional parameters include Drainage Density, Stream Order, Stream Length Ratio, Drainage Texture, Stream Frequency, Elongation Ratio, Circularity Ratio and Form Factor. Relief Aspects give information about three-dimensional parameters like: Relief, Relief Ratio, Ruggedness number, Relative Relief, Relief Ratio. The stream flow hydrograph, run-off volume, run-off intensity, and peak flow are all affected by quantitative hydro morphological characteristics in addition to rainfall, soil, vegetation, and slope (Sahoo et al., 2019). A watershed's geomorphologic attributes can be linked to numerous of hydrological phenomena (Chaudhary \& Kumar, 2018). Drainage network development is influenced by the area's underlying geology, precipitation, and exogenic and endogenic forces (Obi Reddy et al., 2004).It is a powerful method for delineating, updating, and analysing the morphometric parameters of watersheds, and it is more suitable than other methods for effective planning and management of natural resources. (Benukantha Dash et al., 2019). As a result, the main goal is to use Cartosat DEM to evaluate the morphometric parameters of the Arkavathi watershed for soil and water planning and management.

\section{Area of Study}

Arkavathy River originating in Nandi hills of Chikkaballapur district, Karnataka State is a tributary of Cauvery River which joins main Cauvery River after flowing through Ramanagara and Kanakapura districts (Figure 1). The Arkavathi watershed spans about 3833 sq. $\mathrm{km}$ on the western part of Bangalore city of Karnataka. Its latitudinal and longitudinal location is $12 \circ 21^{\prime} \mathrm{N}$ and $77 \circ 10^{\prime} \mathrm{E}$. The watershed contains a mixture of built-up, natural, and agrarian land uses. The watershed can be divided into eight sub watersheds and three major tributaries of Arkavathy that are Kumudavathy, Vrishabhavati, and Suvarnamukhi, as well as eight other sub-watersheds identified by reservoirs or geographical area Hesaraghatta, Kumudavathy TG Halli, Manchanabele, Vrishabhavathi, Suvarnamukhi, Kanakapura, and Harobele). The important reservoirs in the study area differ from the tanks in that they are vigorously managed and provide water to both urban and agricultural users. As a result, we concentrate our hydrological change analysis on tank behaviour.

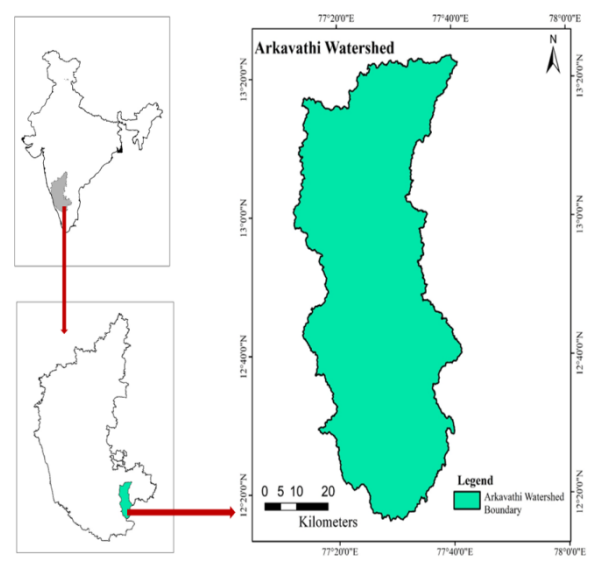

Fig. 1. Location map of the study area

\section{Methodology}

The primary goal of this research is to evaluate the morphometric parameters of the watershed from Cartosat DEM using Remote Sensing \& GIS for planning and management of soil and water conservation measures. The Hydrology tool from the spatial analyst Arc toolbox was used to extract stream orders in Arc GIS 10.3. The extraction function needs two input parameters: Cartosat-1 DEM and the pour point. After the DEM has been processed, Fill sink, flow accumulation and direction, flow length, pour points, snap pour points, stream order, and stream grid were all completed one by one. DEM sinks have been identified and filled to determine the flow direction and flow accumulation. 'The ability to determine the direction of flow from every cell in the raster is one of the keys to deriving hydrologic characteristics about a surface. The flow direction function is used to accomplish this' (Dikpal et al., 2017). Morphometric parameters were derived using different mathematical formulas mentioned in the table no.1.

\section{Results and Discussion}

The parameters that determine the watershed's needs and scope have been calculated. These are described in detail further down on this research paper.

\section{Linear aspects}

"A linear aspect shows the actions of a river and its tributaries from head to mouth, as well as the drainage basin's lithological and structural controls" (MR et al., 2019). Stream orders, stream length ratio, stream length, and bifurcation ratio are all linear aspects. The total number of streams in a watershed is known as the stream number. 
Table 1. Formulae for calculation of various watershed parameters.

\begin{tabular}{|c|c|c|c|}
\hline Aspects & Parameters & Formula & References \\
\hline \multirow{4}{*}{$\begin{array}{l}\text { Linear } \\
\text { Aspects }\end{array}$} & Stream Order $\left(N_{u}\right)$ & Hierarchical Rank & (Strahler, 1957) \\
\hline & Stream Length $\left(L_{u}\right)$ & $L_{u}=\frac{\sum_{i=1}^{N} L_{u}}{N_{u}}$ & (Horton, 1945) \\
\hline & Stream Length Ratio $\left(R_{l}\right)$ & $R_{L}=\frac{L_{u} N_{u}}{L_{u-1}}$ & (Horton, 1945) \\
\hline & Bifurcation Ratio $\left(R_{b}\right)$ & $R_{b}=\frac{N_{u}}{N_{u+1}}$ & (Schumm, 1956) \\
\hline \multirow{8}{*}{$\begin{array}{l}\text { Areal } \\
\text { Aspects }\end{array}$} & Drainage Density $\left(D_{d}\right)$ & $D_{d}=\frac{L_{u}}{A}$ & (Horton, 1945) \\
\hline & Stream Frequency $\left(F_{S}\right)$ & $F_{S}=\frac{N_{u}}{A}$ & (Horton, 1945) \\
\hline & Texture Ratio $(T)$ & $T=\frac{N_{u}}{P}$ & (Smith, 1950) \\
\hline & Form Factor $\left(F_{f}\right)$ & $F_{f}=\frac{A}{\left(L_{b}\right)^{2}}$ & (Horton, 1945) \\
\hline & Circulatory ratio $\left(R_{c}\right)$ & $R_{c}=\frac{4 \times \pi \times A}{P^{2}}$ & (Miller, 1953) \\
\hline & Elongation Ratio $\left(R_{e}\right)$ & $R_{e}=\frac{\sqrt[2]{\frac{A}{\pi}}}{L}$ & (Schumm, 1956) \\
\hline & Compactness Coefficient $\left(C_{c}\right)$ & $C_{c}=0.2821(P / A 0.5)$ & (Horton, 1945) \\
\hline & Length of overland flow $(L o f)$ & $\operatorname{Lof}=1 / 2 D d$ & (Horton, 1945) \\
\hline \multirow{6}{*}{$\begin{array}{l}\text { Relief } \\
\text { Aspects }\end{array}$} & $H$ & $H$ is the maximum elevation & \\
\hline & $h$ & $h$ is the minimum elevation & \\
\hline & Relief $(R)$ & $R=H h$ & \\
\hline & Relief ratio $\left(R_{h}\right)$ & $R_{h}=\frac{H}{L_{b}}$ & (Schumm, 1956) \\
\hline & Ruggedness number $\left(R_{n}\right)$ & $R_{n}=R \times D d$ & (Schumm, 1956) \\
\hline & Relative Relief $\left(R_{r}\right)$ & $R_{r}=\frac{H}{P} \times 100$ & (Melton, 1957) \\
\hline
\end{tabular}

Table 2. Stream Analysis of Arkavthi Watershed

\begin{tabular}{|c|c|c|c|c|c|c|c|c|c|c|c|}
\hline \multirow{2}{*}{ Sub watersheds } & \multirow{2}{*}{$\begin{array}{l}\text { Area in } \\
\text { Sq km }\end{array}$} & \multirow{2}{*}{$\begin{array}{l}\text { Perimeter } \\
\text { km }\end{array}$} & \multirow{2}{*}{$\begin{array}{l}\text { Length } \\
\text { in } \mathrm{Km}\end{array}$} & \multicolumn{8}{|c|}{ No. of Streams of every Order $(\mathrm{Nu})$} \\
\hline & & & & 1 & 2 & 3 & 4 & 5 & 6 & 7 & Total \\
\hline Hesarghatta & 607.21 & 138.11 & 39.4 & 301 & 61 & 16 & 5 & 2 & 1 & - & 386 \\
\hline Kumudavathy & 440.74 & 122.22 & 42.8 & 245 & 50 & 9 & 3 & 1 & - & - & 308 \\
\hline TG Halli & 396.63 & 129.05 & 38.22 & 223 & 48 & 13 & 3 & 1 & 1 & - & 289 \\
\hline Manchanabele & 515.75 & 185.17 & 63.07 & 270 & 59 & 14 & 1 & - & 1 & - & 345 \\
\hline Vrishabhavathi & 563.04 & 143.86 & 49.49 & 305 & 54 & 15 & 4 & 1 & - & - & 379 \\
\hline Suvarnamukhi & 315.57 & 120.42 & 41.91 & 165 & 40 & 9 & 1 & 1 & 1 & - & 217 \\
\hline Kanakapura & 429.91 & 122.9 & 37.42 & 235 & 48 & 10 & 3 & 1 & - & - & 297 \\
\hline Harobele & 891.49 & 183.13 & 41.26 & 436 & 103 & 24 & 4 & 1 & 2 & 1 & 571 \\
\hline Arkavathiwatershed & 4160.34 & 484.4 & 160.07 & 2180 & 463 & 110 & 24 & 8 & 3 & 1 & 2789 \\
\hline
\end{tabular}

\section{Stream orders $\left(N_{u}\right)$}

Stream ordering is the first step of quantitative analysis of the watershed (Pareta \& Pareta, 2012). "Stream number refers to the count of stream channels in their order"(Chorley, 1995). Stream order of Arkavathi watershed is characterize by dendritic drainage pattern and branching of tributaries flowing in many directions and almost any angles. The dendritic pattern indicates the presence of uniform resistance of rock to the drainage in the basin (Harsha et al., 2020). The Arkavathi watershed is allocated as seven order stream. There are nearly 2789 stream orders in the Arkavathi Watershed, with 2180 being 1st order streams, 463 being 2 nd order streams, 110 in 3 rd order streams, 24 in 4 th order streams, 8 in 5 th order streams, 3 in 6 th order streams, and one being the main river as seventh order stream. Out of all sub watersheds,
Harobele has the highest stream number of 571 followed by Heserghetta, Vrishabhavathi and Manchanabele whereas Suvarnamukhi has the lowest stream number of 217 among all other sub watersheds.

\section{Stream length $\left(L_{u}\right)$}

In general, the total length of stream segments is greatest in first-order streams and decreases as the stream order increases (Pande \& Moharir, 2017). It is a noteworthy hydrological aspect of the watershed since it shows the character of surface runoff, and streams with shorter lengths indicate a steeper slope and finer texture in the area. 'Streams with longer lengths generally have a flatter gradient. The total length of stream segments is typically greatest in first-order streams and decreases as stream order increases' (Srivastava et 
al., 2014). In the Arkavathi watershed, in first order streams, the total length of stream segments is greater, and as stream order increases, the total length of stream segments decreases. This is a usual trend and specifies that the topography is gently sloping, low relief and homogenous lithology. The mean stream length is calculated by dividing the total length of channel $L_{u}$ of order $\mathrm{u}$ by the number of stream segments $N_{u}$ of that order, thus:

$$
L_{u}=\frac{\sum_{i=1}^{N} L_{u}}{N_{u}}
$$

Generally, The Lu rises as the number of orders rises. It can be seen that the highest stream length of the first order stream is of $465.48 \mathrm{~km}$ in Harobele whereas Suwarnamukhi has the lowest stream length of $165 \mathrm{~km}$ in first order stream. The general length of the watershed's 1 st order stream is 2085.84 $\mathrm{km}$, which gradually decreases to $1077.72 \mathrm{~km}$ in 2 nd order stream, $550.92 \mathrm{~km}$ in $3 \mathrm{rd}$ order stream, $244.21 \mathrm{~km}$ in 4 th order stream, $124.21 \mathrm{~km}$ in 5 th order stream, $100.78 \mathrm{~km}$ in the 6th order stream, and $44.19 \mathrm{~km}$ in the 7th order stream.

\section{Stream length ratio}

The study watershed's stream length ratio $\left(R_{L}\right)$ was determined by dividing the mean length of a stream with unique order by the mean length of the next lower ordered stream. "Stream Length ratio $\left(R_{L}\right)$ is defined as the ratio of the mean length of the one order to the next lower order of the stream segment" (Chorley, 1995). Another advantage of stream length ratio is that it can provide a general indication of the area's geomorphic evolution stage. As a result, the change in stream length downstream indicates that the watershed is in its late stages of geomorphic development (Moges \& Bhole, 2015; Pande \& Moharir, 2017).

The length ratio is calculated as follows:

$$
R_{L}=\frac{L_{u}}{L_{u-1}}
$$

where, $R_{L}=$ Stream length ratio, $L_{u}=$ the total stream length of the order ' $\mathrm{u}$ ' and $L_{u-1}=$ the total stream length of its next lower order.

The stream length ratio, among 8 sub watersheds, varies from 0.19 to 3.55. The higher the stream length ratio, the more erosion activity there is. The progression of RL from lower to higher orders is a sign of geomorphic maturity (Thomas et al., 2010). The value ranges from 0.19 to 3.55 , with the lowest value representing the majority of first-order streams in the watershed's upper reaches.

\section{Bifurcation ratio}

The term "bifurcation ratio" $\left(R_{b}\right)$ can, according to (Schumm, 1956), be defined by means of the ratio in between the stream segments of each order and the following higher order segment (Schumm, 1956). The bifurcation ratio was used by (Horton, 1945) as a measure of relief and dissertation (Chorley, 1995). Higher $R_{b}$ values are indicative of greater structural control in the network (Das et al., 2016). The overall bifurcation ratio of Arkavathi watershed is 3.53. The $R_{b}$ values in the study area's sub-watersheds range from 2.67 to 3.8 , indicating that all of the sub-watersheds are classified as regular basins. In the current study, Higher $R_{b}$ values indicate that the drainage pattern is under strong structural control, whereas lower values indicate that the drainage pattern is unaffected by structural disturbances.

$$
R_{b}=\frac{N_{u}}{N_{u+1}}
$$

where, $N_{u}=$ the total number of stream segment of order "u"; and $L_{u+1}=$ the number of a segment of next higher order.

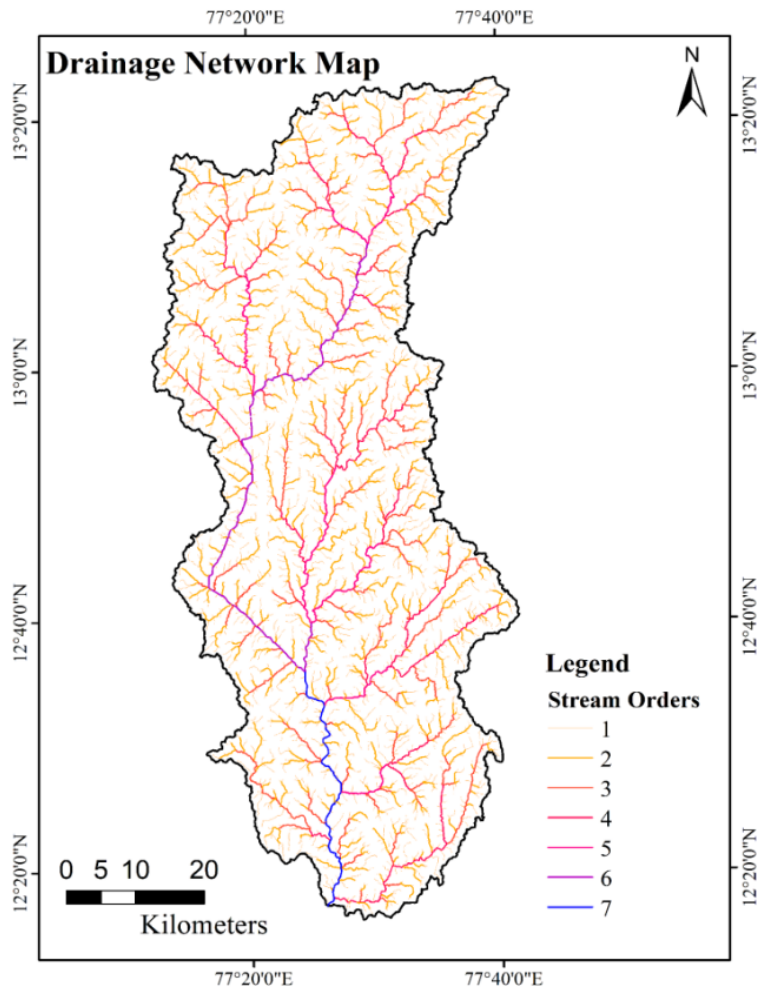

Fig. 2. Drainage Network Map

\section{Areal aspects}

The influence of lithology, geological structure, climatic conditions, and the denudation history is reflected in the areal aspects of a watershed. The runoff and sediment transport processes are greatly influenced by the form of a watershed. The rate at which water enters the stream is also determined by the shape of the catchment (Khedkar et al., 2021). Aerial 
Table 3. No. of stream and Bifurcation ratio of Arkavthi Watershed

\begin{tabular}{|c|c|c|c|c|c|c|c|c|c|}
\hline \multirow{2}{*}{ Sub watersheds } & \multicolumn{8}{|c|}{ No. of Streams of each Order $(\mathrm{Nu})$} & \multirow{2}{*}{$\begin{array}{l}\text { Bifurcation } \\
\text { Ratio (Rb) }\end{array}$} \\
\hline & 1 & 2 & 3 & 4 & 5 & 6 & 7 & Total & \\
\hline Hesarghatta & 289.5 & 147.03 & 73.66 & 45.01 & 20.62 & 5.75 & - & 581.57 & 2.74 \\
\hline Kumudavathy & 208.76 & 124.27 & 50.16 & 27.62 & 19.49 & - & - & 430.3 & 2.74 \\
\hline TG Halli & 193.52 & 110.73 & 55.73 & 9.42 & 5.18 & 33.01 & - & 407.59 & 2.78 \\
\hline Manchanabele & 267.43 & 138.63 & 50.52 & 12.86 & - & 51.65 & - & 521.09 & 3.8 \\
\hline Vrishabhavathi & 279.71 & 139.55 & 93.29 & 39.46 & 28.37 & - & - & 580.38 & 2.83 \\
\hline Suvarnamukhi & 165.42 & 90.71 & 41.25 & 10.87 & 24.59 & 8.09 & - & 340.93 & 3.26 \\
\hline Kanakapura & 216.02 & 113.3 & 56.41 & 45.69 & 13.85 & - & - & 445.27 & 2.67 \\
\hline Harobele & 465.48 & 213.5 & 129.9 & 53.28 & 12.11 & 2.28 & 44.1 & 920.74 & 3.5 \\
\hline Arkavathiwatershed & 2085.84 & 1077.72 & 550.92 & 244.21 & 124.21 & 100.78 & 44.1 & 4227.9 & 3.53 \\
\hline
\end{tabular}

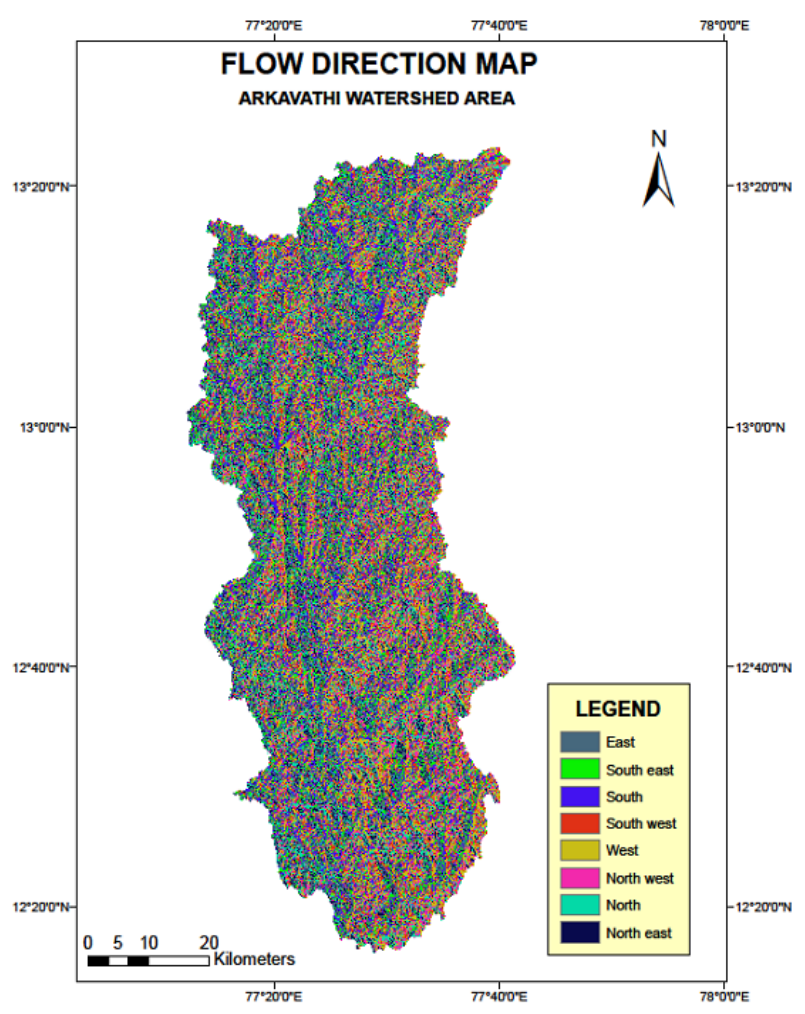

Fig. 3. Flow Direction Map

aspects comprise morphometric parameters such as drainage density $\left(D_{d}\right)$, Form Factor $\left(F_{f}\right)$, elongation ratio $\left(R_{e}\right)$, stream frequency $\left(F_{s}\right)$, Texture Ratio $(\mathrm{T})$, Compactness Coefficient $\left(C_{c}\right)$, circulatory ratio $\left(R_{c}\right)$ and overland flow length (Lof). The areal aspects are two dimensional properties. The overall area of the watershed is $4160.34 \mathrm{sq} \mathrm{km}$.

\section{Drainage Density $\left(D_{d}\right)$}

$D_{d}$ is a fluvial dissection degree that is influenced by a variety of factors, including erosion resistance, infiltration capacity, vegetation cover, surface roughness and run-off intensity index, as well as climatic conditions (Ahmed et al., 2010; Langbein; W.B., 1947; Soni, 2017) The drainage density of the study area is $1.01 \mathrm{Km}-1$ while among the 8 sub watersheds, the drainage density ranges from 0.96 to $1.08 \mathrm{Km}-1$ which indicate a low drainage density. The low drainage density results low overflow land, lesser amount of tributaries, more infiltration and more ground water storage. Heserghetta has the lowest drainage density of $0.96 \mathrm{~km}-1$ whereas Suvarnamukhi has the highest drainage density in the watershed which is $1.08 \mathrm{~km}-1$.

\section{Stream Frequency $\left(F_{s}\right)$}

Stream frequency is associated with lithological features. "The no. of stream segments per unit area is named as Stream Frequency $\left(F_{s}\right)$ "' (Smith, 1950). Higher SF values indicate less resistant rocks, which could contribute to increased erosion in the basin (Das et al., 2016). The stream frequency for this analysis is 0.67 .Total Stream frequency is $0.67 \mathrm{~km}-2$. The stream frequency for the sub-watersheds ranges from 0.64 $0.73 \mathrm{Km}-2$.

\section{Drainage Texture (T)}

The total stream divisions of all orders in the study area per watershed perimeter are known as drainage texture. The underlying lithology, infiltration potential, and relief aspect of the landscape, as well as natural factors such as climate, vegetation, rock, and soil, relief forms and stage of growth, altogether influence drainage texture. (Smith, 1950) divided drainage texture into five categories: very coarse (class 2), coarse (2-4), moderate (4-6), good (6-8), and very fine $(>8)$. Because of the higher slope, very fine drainage texture reflects higher erosion rates besides fewer probabilities for groundwater recharge. The Drainage texture of whole Arkavathi watershed is 5.76 which are moderate. The drainage texture of the sub watershed ranges from 1.08 in suvarnamukhi sub watershed to 3.11 in Harobole. 
Form Factor $\left(F_{f}\right)$

"Horton defines the $F_{f}$ form factor as a watershed area (A) square dimensionless ratio to watershed length $(L)$." Because of the steeper slope, the minute drainage texture reflects greater erosion rates besides fewer opportunities for groundwater restoration. Watersheds with a higher form factor are circular with high peak flows for a shorter period of time, while elongated watersheds with lower form factor values have low peak flows for a longer period of time. For the current study area is having low value form factor which is 0.16 .

$$
F_{f}=\frac{A}{\left(L_{b}\right)^{2}}
$$

where, $F_{f}$ is the form factor, $\left(L_{b}\right)^{2}$ is the total length of watershed and $A$ is the total area of watershed.

The form factor of sub-watersheds ranges from 0.13 to 0.52 . The analysis shows that the sub watersheds are more or less elongated.

\section{Circulatory ratio $\left(R_{c}\right)$}

The circularity ratio is a number that ranges from 0 (in line) to 1 (out of line) (in a circle). The $R_{c}$ of the watershed is 0.22 while those of the $8 \mathrm{sub}$ watersheds varies from 0.03 to 0.37 . The higher the value, the higher is the circularity ratio. It is an important ratio that specifies a watershed's dendritic stage. The circularity ratio was found to be 0.33 in a recent study.

$$
R_{c}=\frac{4 \times \pi \times A}{P^{2}}
$$

where, $R_{c}=$ Circularity ratio, $A=$ Watershed area and $P^{2}=$ Perimeter of watershed

\section{Elongation Ratio $\left(R_{e}\right)$}

"The elongation ratio is the ratio of the diameter of a circle with the same area as the watershed to the basin's maximum length" (Schumm, 1956). " $R_{e}$ ranges from 0 (in a highly elongated shape) to unity (1.0) (in circular shape)" (Kumar \& Chaudhary, 2016). Smaller form factor specifies that the study area is elongated.

\begin{tabular}{ll}
\hline Elongation ratio & Shape of the basin \\
\hline$<0.7$ & Elongated \\
$0.7-0.8$ & Less Elongated \\
$0.8-0.9$ & Oval \\
$>0.9$ & Circular \\
\hline
\end{tabular}

$R_{e}$ For the entire watershed is 0.45 however in the $8 \mathrm{sub}$ watersheds the value varies from 0.41 to 0.82 . It demonstrates that the Arkavathi watershed has an elongated shape.

$$
R_{e}=\frac{\sqrt[2]{\frac{A}{\pi}}}{L}
$$

where, $R_{e}=$ Elongation ratio, $L=$ Total length of watershed and $A=$ Total area of watershed.

\section{Compactness Coefficient $\left(C_{c}\right)$}

Gravelius states that (1914), a watershed's coefficient is the ratio of the watershed's perimeter to the circumference of a circular area. The $C_{c}$ is unaffected by the size of the watershed and is only affected by the slope.

$C_{c}=0.2821(P / A 0.5)$

where, $C_{c}$ (Horton, 1945) =Compactness Coefficient $0.2821=$ Constant value, $P=$ Perimeter and $A=$ Basin area.

The value of $C_{c}$ in the Arkavathi watershed ranges from 1.06 to 2.32 among all the 8 sub watersheds. Whereas the overall value of $C_{c}$ of Arkavathi watershed is 2.13.

\section{Length of overland flow (Lof)}

The Lof is the distance that water travels over land until it is concentrated into specific stream channels. Overland flow length is equal to half the inverse of drainage density. (Horton, 1945)is a term used to describe the time it takes for water to flow across the ground until it condenses into specific stream channels (Chorley, 1995). $D_{d}$ in calculating Length of overland flow must be in $\mathrm{km} / \mathrm{km} 2$. Amount of rain, infiltration rate, soil conditions, vegetation, and other factors all affect the length of an overland flow (Prakash et al., 2016). The three classes of Lg are low $(<0.2)$, medium $(0.2-0.3)$, and high $(>0.3)$. A high value of $\mathrm{Lg}$ results moderate slopes besides lengthy flow paths maximum infiltration, and low runoff (Vinutha, 2014).

Among the sub watersheds it varies from $0.48 \mathrm{~km}$ (Hesarghatta sub watershed) to $0.54 \mathrm{~km}$ (Suvarnamukhi sub watershed). The length of the overland flow of the whole watershed is $0.51 \mathrm{~km}$ which means the $\mathrm{Lg}$ has a high value

\begin{tabular}{|c|c|c|c|c|c|c|c|c|}
\hline \multirow[t]{2}{*}{ Sub watershed } & \multicolumn{6}{|c|}{$\begin{array}{l}\text { Derived morphometric } \\
\text { parameters }\end{array}$} & \multirow[b]{2}{*}{$\mathrm{Cc}$} & \multirow[b]{2}{*}{ Lo } \\
\hline & Dd & Fs & $\mathbf{T}$ & Ff & Rc & $\operatorname{Re}$ & & \\
\hline Hesarghatta & 0.96 & 0.64 & 2.8 & 0.39 & 0.04 & 0.71 & 1.6 & 0.48 \\
\hline Kumudavathy & 0.98 & 0.7 & 2.52 & 0.24 & 0.37 & 0.55 & 1.65 & 0.49 \\
\hline TG Halli & 1.02 & 0.73 & 2.24 & 0.27 & 0.03 & 0.59 & 1.84 & 0.51 \\
\hline $\begin{array}{l}\text { Manchan- } \\
\text { abele }\end{array}$ & 1.01 & 0.67 & 1.86 & 0.13 & 0.19 & 0.41 & 2.32 & 0.51 \\
\hline $\begin{array}{l}\text { Vrishabha- } \\
\text { vathi }\end{array}$ & 1.03 & 0.67 & 2.63 & 0.23 & 0.34 & 0.54 & 1.72 & 0.52 \\
\hline $\begin{array}{l}\text { Suvarna- } \\
\text { mukhi }\end{array}$ & 1.08 & 0.69 & 1.8 & 0.18 & 0.27 & 0.48 & 1.93 & 0.54 \\
\hline Kanakapura & 1.04 & 0.69 & 2.41 & 0.31 & 0.36 & 0.63 & 1.69 & 0.52 \\
\hline Harobele & 1.03 & 0.64 & 3.11 & 0.52 & 0.33 & 0.82 & 1.74 & 0.52 \\
\hline $\begin{array}{l}\text { Arkavathi } \\
\text { watershed }\end{array}$ & 1.01 & 0.67 & 5.76 & 0.16 & 0.22 & 0.45 & 2.13 & 0.51 \\
\hline
\end{tabular}
with gentle slopes and long flow paths.

Table 4. Areal Aspects of Arkavathi Watershed 


\section{Relief aspects}

The difference in elevation between a basin's lowest and highest point is known as relief (Afreeda et al., 2018). The 3D landscapes of a watershed including the vertical dimension of landforms' area and volume which is related to the relief aspects of drainage basins. The relief aspects considered for the current study include watershed relief, relief ratio, ruggedness number and relative relief.

\section{Watershed relief}

The elevation variance among the furthermost point on the water divide line besides the watershed's discharge point is known as watershed relief. The elevation variation among the mouth and the highest point on the perimeter which is stated in meters is known as watershed relief.

$H=$ (Difference in elevation of the watershed's highest point) - (Difference in elevation of the watershed's outlet)

The highest relief is at an elevation of $1397 \mathrm{mtrs}$ above MSL at Heserghetta sub watershed. The lowest relief was found at Harobole, which is 279 meters above sea level. The watershed's total relief was estimated to be $1118 \mathrm{mtrs}$.

\section{Relief Ratio $\left(R_{h}\right)$}

It's the proportion of the basin's total relief to its longest dimension parallel to the main drainage line. It's the ratio of stream length to relief. It's the ratio of watershed's stream length to relief (Kumar \& Chaudhary, 2016).

$$
R_{h}=\frac{H}{L_{b}} \times 1000
$$

Relief ratio was described by (Schumm, 1956) as the ratio of total watershed relief to the maximum length of the watershed. The relief ratio came out to be 0.006 . For the study area, the relief ratio values vary from 0.018 (Harobole sub watershed) to 0.006 (TG Halli Sub watershed).

\section{Ruggedness number}

According to (Strahler, 1957), the ruggedness number is calculated by multiplying the watershed relief by the drainage density. In the watershed area, higher values of the ruggedness number indicate that both relief and drainage density are increased Watersheds with a low ruggedness rating are less susceptible to soil erosion and have more technical complexity in relation to relief and drainage density. The ruggedness number value for the watersheds ranges from 248.88 (TG Halli sub watershed) to 806.49 (Harobole sub watershed). The ruggedness number for the whole watershed is 1129.18 .

It is calculated by the equation,

$R_{n}=R \times D d$

where, $R_{n}=$ Ruggedness number, $R=$ Watershed relief $(\mathrm{km})$ and $D d=$ Drainage density $\mathrm{km} / \mathrm{Km}$.

\section{Relative relief}

Relative relief is well-defined as ratio of overall watershed relief to watershed perimeter. By the equation, it comes out to be 280.18 .

$$
R_{r}=\frac{H}{P} \times 100
$$

where, $R_{r}=$ Relative relief, $H=$ Maximum relief $(\mathrm{km})$ and $P=$ Perimeter $(\mathrm{km})$

Table 5. Relief Aspect of Arkavathi watershed.

\begin{tabular}{lllllll}
\hline \multirow{2}{*}{ Sub watershed } & \multicolumn{7}{c}{ Relief Aspects } \\
\cline { 2 - 7 } & $\begin{array}{l}\text { H in } \\
\text { m }\end{array}$ & h in & R & Rh & Rn & Rr \\
& 1397 & 748 & 649 & 0.016 & 623.04 & 469.92 \\
Hesarghatta & 1188 & 700 & 488 & 0.011 & 478.24 & 399.28 \\
Kumudavathy & 876 & 632 & 244 & 0.006 & 248.88 & 189.07 \\
TG Halli & 1133 & 538 & 595 & 0.009 & 600.95 & 321.33 \\
Manchanabele & 896 & 545 & 351 & 0.007 & 361.53 & 243.99 \\
Vrishabhavathi & 948 & 537 & 411 & 0.009 & 443.88 & 341.31 \\
Suvarnamukhi & 1080 & 512 & 568 & 0.015 & 590.72 & 462.16 \\
Kanakapura & 1062 & 279 & 783 & 0.018 & 806.49 & 427.57 \\
Harobele & 1397 & 279 & 1118 & 0.006 & 1129.18 & 230.8 \\
Arkavathi & & & & & & \\
watershed & & & & & & \\
\hline
\end{tabular}

\section{Conclusion}

The shape of the stream network in the Arkavathi watershed evolved in response to the hydrologic processes that prevailed in the area, determining the potential efficiency of the watershed.This paper addresses a detailed analysis of some morphometric parameters, their value ranges, impact, and overlap, as well as the quality of input data.From the quantitative study, it can be seen that Arkavathi watershed has a dendritic pattern of drainage as it develops a random branching network and falls in area that has uniform bedrock. The overall bifurcation ratio of Arkavathi watershed is 3.53 which indicate a moderate drainage density. Total Stream frequency of the watershed is $0.67 \mathrm{~km}-2$. The Stream frequency for all subwatersheds varies from $0.64-0.73 \mathrm{Km}-2$. The drainage density came out to be $1.01 \mathrm{Km}-1$ while among the 8 sub watersheds, Drainage density varies between 0.96 and $1.08 \mathrm{~km}-1$. which indicate a low drainage density. The value of circularity ratio and form factor indicates that the sub-watersheds are elongated in some way. The length of the overland flow of the whole watershed is $0.51 \mathrm{~km}$ which means the Lg has a high value with gentle slopes and long flow paths which results to lesser flood risk and soil erosion. The watershed's relief ratio was found to be 0.006 which results low relief in the watershed. The watershed's morphometric analysis yields dimensionless parameters. This study hopes that the information and knowledge generated will guide informed planning and 
decision making for overall information about the morphometric and hydrological parameters of the watershed, thereby assisting in proper resource management.

$(1-9)$

\section{References}

1) Afreeda E, Kannan B, Scholar P. Morphological Parameter Estimation Derived From DEM Using GIS and Remote Sensing Techniques. International Journal of Engineering Science and Computing. 2018;8(3):1619216196.

2) Ahmed SA, Chandrashekarappa KN, Raj SK, Nischitha V, Kavitha G. Evaluation of morphometric parameters derived from ASTER and SRTM DEM - A study on Bandihole sub-watershed basin in Karnataka. Journal of the Indian Society of Remote Sensing. 2010;38(2):227-238. Available from: https://dx.doi.org/10.1007/s12524-010-0029-3.

3) Chandrashekar H, Lokesh KV, Sameena M, roopa J, Ranganna G. GIS Based Morphometric Analysis of Two Reservoir Catchments of Arkavati River, Ramanagaram District, Karnataka. Aquatic Procedia. 2015;4:13451353. Available from: https://dx.doi.org/10.1016/j.aqpro.2015.02.175.

4) Chaudhary BS, Kumar S. Identification of Groundwater Potential Zones using Remote Sensing and GIS of K-J Watershed, India. Journal of the
Geological Society of India. 2018;91(6):717-721. Available from: https: //dx.doi.org/10.1007/s12594-018-0929-3.

5) Horton RE. Erosional development of streams and their drainage basins: Hydrophysical approach to quantitative morphology. Bulletin of the Geological Society of America. Geological Society of America Bulletin. 1945;56(3):275. Available from: https://dx.doi.org/10.1130/ 0016-7606(1945)56[275:edosat]2.0.co;2.

6) Das S, Patel PP, Sengupta S. Evaluation of different digital elevation models for analyzing drainage morphometric parameters in a mountainous terrain: a case study of the Supin-Upper Tons Basin, Indian Himalayas. SpringerPlus. 2016;5(1):1-38. Available from: https://dx.doi.org/10.1186/ s40064-016-3207-0.

7) Dikpal RL, Prasad TJR, Satish K. Evaluation of morphometric parameters derived from Cartosat-1 DEM using remote sensing and GIS techniques for Budigere Amanikere watershed, Dakshina Pinakini Basin, Karnataka, India. Applied Water Science. 2017;7(8):4399-4414. Available from: https://dx.doi.org/10.1007/s13201-017-0585-6.

8) Hadley RF, Schumm SA. Sediment sources and drainage basin characteristics in upper Cheyenne River basin. Water Supply Paper 1531B. In: Geological Survey. 1961;p. 137-196.

9) Harsha J, Ravikumar AS, Shivakumar BL. Evaluation of morphometric parameters and hypsometric curve of Arkavathy river basin using RS and GIS techniques. Applied Water Science. 2020;10(3):1-15. Available from: https://dx.doi.org/10.1007/s13201-020-1164-9. 